\title{
STUDIES ON A NOVEL ANTITUMOR ANTIBIOTIC, PHENAZINOMYCIN: TAXONOMY, FERMENTATION, ISOLATION, AND PHYSICO- CHEMICAL AND BIOLOGICAL CHARACTERISTICS
}

\author{
Satoshi Ōmura, Shigeru EdA ${ }^{\dagger}$, Shinj Funayama, Kanki Komiyama, \\ YŌKO TAKAHASHI and H. BOYD WOODRUFF ${ }^{a}$ \\ The Kitasato Institute, and School of Pharmaceutical Sciences, Kitasato University, \\ 5-9-1 Shirokane, Minato-ku, Tokyo 108, Japan \\ ${ }^{a}$ Soil Microbiology Associates, 797 Valley Road, Watchung, NJ, U.S.A.
}

(Received for publication March 10, 1989)

\begin{abstract}
A new antibiotic, phenazinomycin $\left(\mathrm{C}_{97} \mathrm{H}_{32} \mathrm{~N}_{2} \mathrm{O}\right.$, MW 400), was isolated from the cultural mycelium of Streptomyces sp. WK-2057. This antibiotic possesses antibacterial activities against Gram-positive bacteria in vitro, direct cytotoxic activities against $\mathrm{HeLa} \mathbf{S}_{3}, \mathrm{P} 388$ and P388 doxorubicin-resistant cells in vitro and antitumor activities against experimental murine tumors in vivo.
\end{abstract}

In the course of a screening program for new types of antibiotics showing cytocidal activity obtained from microorganisms, phenazinomycin was discovered from the fermentation broth of Streptomyces sp. WK-2057, which was isolated from a soil sample. The present paper deals with taxonomic studies of the producing strain, and the production, isolation and physico-chemical properties of the new antibiotic. The biological activity of phenazinomycin against tumor cells and microorganisms is also presented.

\section{Materials and Methods}

\section{Taxonomic Studies}

For taxonomic studies, most cultures were grown in accordance with methods adopted by the International Streptomyces Project (ISP) ${ }^{1}$. For experiments on cultural properties, all cultures were incubated at $27^{\circ} \mathrm{C}$ and were observed for $15 \sim 20$ days. The color recorded for mature cultures was described according to the "Color Harmony Manual"'). Physiological properties including utilization of carbon sources were examined by the method of PRIDHAM and GoTTLIEB ${ }^{32}$. The type of diaminopimelic acid in the cell wall was analyzed by the method of BECKER et al. ${ }^{4}$.

\section{Fermentation}

The stock culture of the producing organism was inoculated into three 500-ml Sakaguchi flasks, each containing $100 \mathrm{ml}$ of the seed medium consisting of glycerol $2.0 \%$, soybean meal powder $2.0 \%$ and $\mathrm{NaCl} 0.5 \%$ (adjusted to $\mathrm{pH} 7.0$ before sterilization). The flasks were incubated at $27^{\circ} \mathrm{C}$ for 72 hours on a reciprocal shaker. The resulting culture $(3 \times 100 \mathrm{ml})$ was transferred to three 30 -liter jar fermenters, each of which containing 20 liters of the producing medium consisting of glucose $2.0 \%$, peptone $0.5 \%$, meat extract $0.5 \%$, dry yeast $0.3 \%, \mathrm{NaCl} 0.5 \%$ and $\mathrm{CaCO}_{3} 0.3 \%$ (adjusted to $\mathrm{pH} 7.0$ before sterilization), and the fermentation was carried out at $27^{\circ} \mathrm{C}$ for 96 hours with an agitation rate of $160 \mathrm{rpm}$ and an aeration rate of 20 liters/minute. Detection of the antibiotic in the fermentation broth was followed by a cytocidal assay using P388 doxorubicin-resistant (P388/ADM) cells described below or by HPLC analysis (column: Merck pre-packed column SI $60(4 \times 250 \mathrm{~mm})$, Merck,

t Present address: Pharmaceutical Research Laboratories, Japan Tobacco Inc., 6-2 Umegaoka, Midori-ku, Yokohama 227, Japan. 
solvent: $\mathrm{CH}_{3} \mathrm{Cl}-\mathrm{MeOH}(20: 1)$, detection: UV $\left.260 \mathrm{~nm}\right)$.

After 96 hours of fermentation, the amount of phenazinomycin in the mycelium reached a maximum $(20 \mu \mathrm{g} / \mathrm{ml})$.

Antimicrobial Activity

The antimicrobial activity of phenazinomycin was determined by the agar dilution method using Mueller-Hinton agar medium (Difco) for bacteria and potato agar medium for fungi and yeasts.

Antimicrobial activity was observed after 24 hours of incubation at $37^{\circ} \mathrm{C}$ for bacteria or longer incubation at $27^{\circ} \mathrm{C}$ for fungi or yeasts.

\section{Effect of Phenazinomycin on HeLa $\mathrm{S}_{3}, \mathrm{P} 388$ and P388/ADM Cells}

HeLa $S_{3}$ cells were maintained in monolayers in EAGLE's minimum essential medium supplemented with $10 \%$ bovine serum and antibiotics $(100 \mathrm{U} / \mathrm{ml}$ of benzylpenicillin and $100 \mu \mathrm{g} / \mathrm{ml}$ of streptomycin) at $37^{\circ} \mathrm{C}$. P388 and P388/ADM cells were kindly provided by Dr. M. INABA of the Japanese Foundation of Cancer Research and were maintained in RPMI medium.

To determine the cytotoxicity of phenazinomycin on tumor cells, HeLa $\mathrm{S}_{3}\left(4 \times 10^{4}\right), \mathrm{P} 388\left(5 \times 10^{4}\right)$ or P388/ADM $\left(5 \times 10^{4}\right)$ cells in $2 \mathrm{ml}$ of the medium were placed in $2 \mathrm{~cm}^{2}$-culture plate (Falcon 3047) and incubated for 48 hours at $37^{\circ} \mathrm{C}$ in a $5 \% \mathrm{CO}_{2}-95 \%$ air atmosphere. Each culture dish was filled with fresh medium containing a different concentration of phenazinomycin and incubated for 72 hours. At the end of the incubation period, $\mathrm{HeLa} \mathrm{S}_{3}$ cells were trypsinized to form a single cell suspension, and HeLa $\mathbf{S}_{3}$, P388 and P388/ADM cells were counted using a hemocytometer.

\section{Antitumor Activity}

For determination of antitumor activity of phenazinomycin, male ICR mice weighing $20 \sim 24 \mathrm{~g}$ were purchased from the Shizuoka Laboratory Animal Center (Shizuoka, Japan). Sarcoma 180 ascites tumor cells were maintained by weekly ip passage in ICR mice. Seven to eight animals per group were used in this experiment.

Antitumor activity was evaluated by the increase in life span (ILS): (T/C -1$) \times 100 \%$, where " $T$ " was the mean survival days (MSD) of the treated group and " $C$ " the MSD of the control group.

\section{Results and Discussion}

\section{Taxonomic Studies}

An electron micrograph of strain WK-2057 is shown in Fig. 1. The aerial mycelia were well developed on yeast extract - malt extract agar and were long, with no vertical formation.

Culture characteristics, physiological properties and utilization of carbon sources of strain WK-2057 are shown in Tables $1 \sim 3$, respectively. Cell wall analysis showed the presence of LLdiaminopimelic acid.

Microscopic studies and the cell wall type indicated that strain WK-2057 belongs to the genus Streptomyces.

\section{Isolation and Purification}

The harvested broth $(3 \times 20$ liters $)$ of Streptomyces sp. WK-2057 was centrifuged, and the resulting mycelium was extracted with acetone (20 liters). The acetone extract was concentrated to $c a .2$ liters in vacuo and then extracted
Fig. 1. Scanning electron micrograph of aerial mycelia of Streptomyces sp. WK-2057 on inorganic salts - starch agar.

Bar represents $1 \mu \mathrm{m}$.

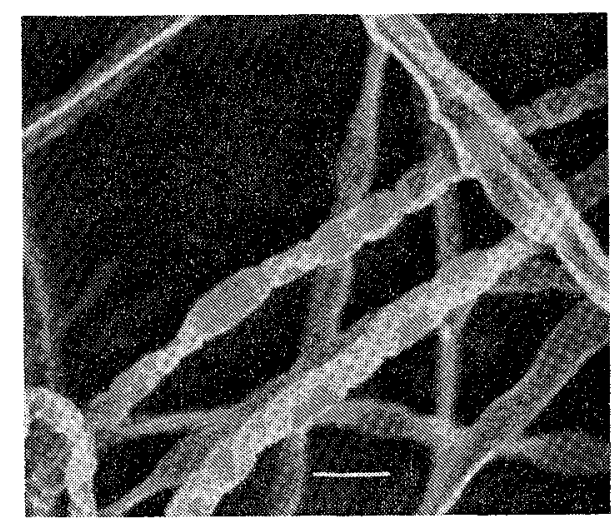


Table 1. Cultural properties of strain WK-2057.

\begin{tabular}{|c|c|c|c|c|}
\hline Medium & $\mathrm{G}$ & $\mathrm{AM}$ & $\mathrm{R}$ & SP \\
\hline $\begin{array}{l}\text { Glucose - } \\
\text { asparagine agar }{ }^{a}\end{array}$ & $\begin{array}{l}\text { Good, } \\
\text { biscuit (2ec) }\end{array}$ & $\begin{array}{l}\text { Moderate, } \\
\text { white (a) }\end{array}$ & $\begin{array}{l}\text { Light wheat ( } 2 \mathrm{ec}) \\
\text { to mustard }(21 \mathrm{e})\end{array}$ & None \\
\hline $\begin{array}{l}\text { Glycerol - } \\
\text { asparagine agar }\end{array}$ & $\begin{array}{l}\text { Good, } \\
\text { bamboo }(2 \mathrm{fb}) \\
\text { to light } \\
\text { mustard tan } \\
(2 \mathrm{ie})\end{array}$ & $\begin{array}{l}\text { Moderate, } \\
\text { white (a) }\end{array}$ & $\begin{array}{l}\text { Bamboo }(2 \mathrm{fb}) \text { to } \\
\text { light mustard tan } \\
(2 \mathrm{ie})\end{array}$ & None \\
\hline $\begin{array}{l}\text { Inorganic salts - } \\
\text { starch agar }\end{array}$ & $\begin{array}{l}\text { Good, } \\
\text { light wheat } \\
\text { (2ea) }\end{array}$ & $\begin{array}{l}\text { Good, } \\
\text { alabaster } \\
\text { tint (13ba) }\end{array}$ & $\begin{array}{l}\text { Covert } \tan (2 \mathrm{ge}) \\
\text { to golden olive } \\
(11 / 2 \mathrm{lg})\end{array}$ & None \\
\hline Tyrosine agar ${ }^{2}$ & $\begin{array}{l}\text { Moderate, } \\
\text { light ivory } \\
\text { (2ca) to } \\
\text { mustard tan } \\
(2 \mathrm{lg})\end{array}$ & None & $\begin{array}{c}\text { Bamboo }(2 \mathrm{fb}) \text { to } \\
\text { camel (3ie) }\end{array}$ & None \\
\hline Oatmeal agar & $\begin{array}{l}\text { Good, } \\
\text { mustard (2le) }\end{array}$ & $\begin{array}{l}\text { Moderate, } \\
\text { alabaster, } \\
\text { tint (13ba) }\end{array}$ & Light ivory (2ca) & None \\
\hline $\begin{array}{l}\text { Yeast extract - } \\
\text { malt extract agar }\end{array}$ & $\begin{array}{l}\text { Good, } \\
\text { dull gold ( } 2 n g)\end{array}$ & None & Mustard gold (2pg) & None \\
\hline Nutrient agar ${ }^{a}$ & $\begin{array}{l}\text { Poor, } \\
\quad \text { putty }(11 / 2 \mathrm{ec})\end{array}$ & None & $\begin{array}{l}\text { Dusty yellow } \\
\text { (1 } 1 / 2 \mathrm{gc})\end{array}$ & None \\
\hline $\begin{array}{l}\text { Peptone - yeast } \\
\text { extract - iron agar }\end{array}$ & $\begin{array}{l}\text { Moderate, } \\
\text { bamboo (2fb) }\end{array}$ & None & $\begin{array}{l}\text { Light ivory (2ca) } \\
\text { to bamboo ( } 2 \mathrm{fb})\end{array}$ & None \\
\hline $\begin{array}{l}\text { Glucose - nitrate } \\
\text { agar }^{b}\end{array}$ & $\begin{array}{l}\text { Poor, } \\
\text { light ivory } \\
(2 \mathrm{ca})\end{array}$ & None & Bamboo (2gc) & None \\
\hline $\begin{array}{l}\text { Sucrose-nitrate } \\
\text { agar }^{b}\end{array}$ & $\begin{array}{l}\text { Moderate, } \\
\text { cream }(11 / 2 \mathrm{ca}) \\
\text { to mistletoe } \\
\text { green }(241 / 2 \mathrm{ig})\end{array}$ & None & $\begin{array}{l}\text { Cream }(11 / 2 \mathrm{ca}) \\
\text { to sage green } \\
(24 \mathrm{ig})\end{array}$ & None \\
\hline $\begin{array}{l}\text { Glycerol - calcium } \\
\text { malate agar }\end{array}$ & $\begin{array}{l}\text { Good, } \\
\text { pearl pink } \\
\text { (3ca) to } \\
\text { topaz }\end{array}$ & $\begin{array}{l}\text { Very poor, } \\
\text { pearl (2ba) }\end{array}$ & $\begin{array}{l}\text { Bamboo }(2 \mathrm{gc}) \text { to } \\
\text { light mustard } \\
\tan (2 \mathrm{ie})\end{array}$ & None \\
\hline $\begin{array}{l}\text { Glucose - peptone } \\
\text { agar }^{\text {b }}\end{array}$ & $\begin{array}{l}\text { Good, } \\
\text { bamboo }(2 \mathrm{gc})\end{array}$ & None & Mustard (2le) & None \\
\hline
\end{tabular}

G: Growth of vegetative mycelium, AM: aerial mycelium, R: reverse, SP: soluble pigment.

a Medium recommended by ISP.

b Medium recommended by $\mathrm{S}$. A. WAKSMAN.

with EtOAc ( 2 liters). The organic layer was dried over $\mathrm{Na}_{2} \mathrm{SO}_{4}$ and concentrated under reduced pressure to give a greenish oil $(c a .12 \mathrm{~g})$.

The oily residue was chromatographed on a silica gel column (Kieselgel 60, Merck, $500 \mathrm{ml}$ ) using a $\mathrm{CHCl}_{3}-\mathrm{MeOH}$ mixture as the developing solvent. Fractions exhibiting cytocidal activity on P388/ADM cells were collected and rechromatographed on a silica gel column using $\mathrm{CHCl}_{3}-\mathrm{MeOH}$ to give crude phenazinomycin (ca. $400 \mathrm{mg}$ ).

The antibiotic was further purified by preparative HPLC (column: Asahipack GS-310H, Asahi Chemical Co., Japan, solvent: $\mathrm{CHCl}_{3}-\mathrm{MeOH}(20: 1)$, detection: UV $\left.260 \mathrm{~nm}\right)$ to give phenazinomycin as dark blue needles. 
Table 2. Physiological characteristics of strain WK-2057 .

$\begin{array}{ll}\text { Nitrate reduction } & \text { Negative } \\ \text { Liquefaction of gelatin }\left(21 \sim 22^{\circ} \mathrm{C}\right) & \text { Negative } \\ \text { Starch hydrolysis } & \text { Positive } \\ \text { Coagulation of milk }\left(37^{\circ} \mathrm{C}\right) & \text { Negative } \\ \text { Peptonization of milk }\left(37^{\circ} \mathrm{C}\right) & \text { Positive } \\ \text { Melanin formation } & \text { Negative } \\ \text { Tyrosinase reaction } & \text { Negative } \\ \text { Production of } \mathrm{H}_{2} \mathrm{~S} & \text { Negative } \\ \text { Cellulolytic activity } & \text { Negative }\end{array}$

a Temperature range for growth $15 \sim 36^{\circ} \mathrm{C}$.

Table 3. Utilization of carbon sources by strain WK-2057.

\begin{tabular}{cl}
\hline Responses & \multicolumn{1}{c}{ Carbon sources } \\
\hline Positive & $\begin{array}{l}\text { D-Glucose, L-arabinose, D-xylose, } \\
\text { raffinose, melibiose, D-mannitol, } \\
\text { D-fructose, L-rhamnose, } i \text {-inositol, } \\
\text { sucrose }\end{array}$ \\
\hline
\end{tabular}

Table 4. Antimicrobial spectrum of phenazinomycin.

\begin{tabular}{|c|c|}
\hline Organism & $\mathrm{MIC}(\mu \mathrm{g} / \mathrm{ml})$ \\
\hline Staphylococcus aureus KB 210 & 12.5 \\
\hline S. aureus FDA 209P & 25.0 \\
\hline Bacillus subtilis KB 211 & 6.3 \\
\hline B. cereus KB 143 & 1.6 \\
\hline Micrococcus luteus KB 212 & 3.1 \\
\hline Mycobacterium smegmatis KB 42 & $>100$ \\
\hline Escherichia coli $\mathrm{NIHJ}$ & $>100$ \\
\hline E. coli NIHJ JC-2 & $>100$ \\
\hline Klebsiella pneumoniae KB 212 & $>100$ \\
\hline Salmonella typhimurium KB 20 & $>100$ \\
\hline Proteus vulgaris KB 127 & $>100$ \\
\hline Pseudomonas aeruginosa KB 115 & $>100$ \\
\hline Candida albicans $\mathrm{KF} 1$ & $>100$ \\
\hline Saccharomyces cerevisiae KF 237 & $>100$ \\
\hline Cryptococcus neoformans $802 \mathrm{KF} 33$ & 100 \\
\hline Microsporum gypseum KF 64 & 50.0 \\
\hline Trichophyton mentagrophytes T-5 KF 213 & 100 \\
\hline Penicillium herquei KF 227 & $>100$ \\
\hline Botrytis cinerea $\mathrm{KF} 241$ & 100 \\
\hline Sclerotinia cinerea KF 181 & 25.0 \\
\hline Piricularia oryzae KF 180 & 12.5 \\
\hline Mucor racemosus KF 223 & $>100$ \\
\hline
\end{tabular}

Table 5. Antitumor activity of phenazinomycin on Sarcoma 180 tumor.

\begin{tabular}{cccc}
\hline $\begin{array}{c}\text { Dose } \\
(\mathrm{mg} / \mathrm{kg} / \text { day })\end{array}$ & MSD (range) & ILS $(\%)$ & $\begin{array}{c}\text { Mean body weight }(\mathrm{g}) \\
\text { (day-9) }\end{array}$ \\
\hline Saline & $10.1(9 \sim 12)$ & 0 & $35.2 \pm 2.4$ \\
22.2 & $24.2(21 \sim 33)$ & 140 & $26.1 \pm 0.9$ \\
11.1 & $20.3(13 \sim 25)$ & 101 & $27.9 \pm 2.3$ \\
5.6 & $13.5(9 \sim 20)$ & 34 & $31.1 \pm 4.3$ \\
2.8 & $14.4(9 \sim 19)$ & 43 & $32.5 \pm 3.0$ \\
\hline
\end{tabular}

Sarcoma 180 cells $\left(1 \times 10^{6}\right)$ were inoculated into ICR mouse.

Mice were administered with phenazinomycin ip on days $1 \sim 9$.

Biological Properties of Phenazinomycin

The antimicrobial activity of phenazinomycin was determined by the agar dilution method. The antibiotic was active against Gram-positive bacteria but inactive or only weakly active against Gram-negative bacteria, yeast and fungi. MICs of phenazinomycin are listed in Table 4.

The cytocidal activity of phenazinomycin was investigated using a strain of human tumor cells and two strains of murine tumor cells in
Table 6. Physico-chemical properties of phenazinomycin.

\begin{tabular}{ll}
\hline Appearance & Dark blue needle \\
Molecular formula & $\mathrm{C}_{27} \mathrm{H}_{32} \mathrm{~N}_{2} \mathrm{O}$ \\
EI-MS $m / z\left(\mathrm{M}^{+}\right)$ & 400 \\
$\mathrm{MP}$ & $113 \sim 118^{\circ} \mathrm{C}$ \\
{$[\alpha]_{\mathrm{D}}^{25}(c 0.45, \mathrm{MeOH})$} & $-49^{\circ}$ \\
$\mathrm{UV} \lambda_{\mathrm{max}}^{\mathrm{MeOH}} \mathrm{nm}(\varepsilon)$ & $240(24,500), 321(27,200)$, \\
& $745(6,100)$ \\
$\mathrm{IR} \nu_{\max } \mathrm{cm}^{-1}$ & $1633,1501,1467,1446$ \\
$\mathrm{TLC}\left(\mathrm{SiO}_{2}\right) \mathrm{Rf}:$ & \\
$\mathrm{CHCl}-\mathrm{MeOH}(40: 1)$ & 0.33 \\
$\mathrm{EtOAc}-\mathrm{MeOH}(10: 1)$ & 0.28 \\
\hline
\end{tabular}
vitro. When the cells were exposed to the antibiotic for 3 days, the growths of HeLa $\mathrm{S}_{3}, \mathrm{P} 388$ and P388/ADM cells were inhibited at concentrations of $0.78,25$ and $3.1 \mu \mathrm{g} / \mathrm{ml}$, respectively. 
Fig. 2. IR spectrum of phenazinomycin $(\mathrm{KBr})$.

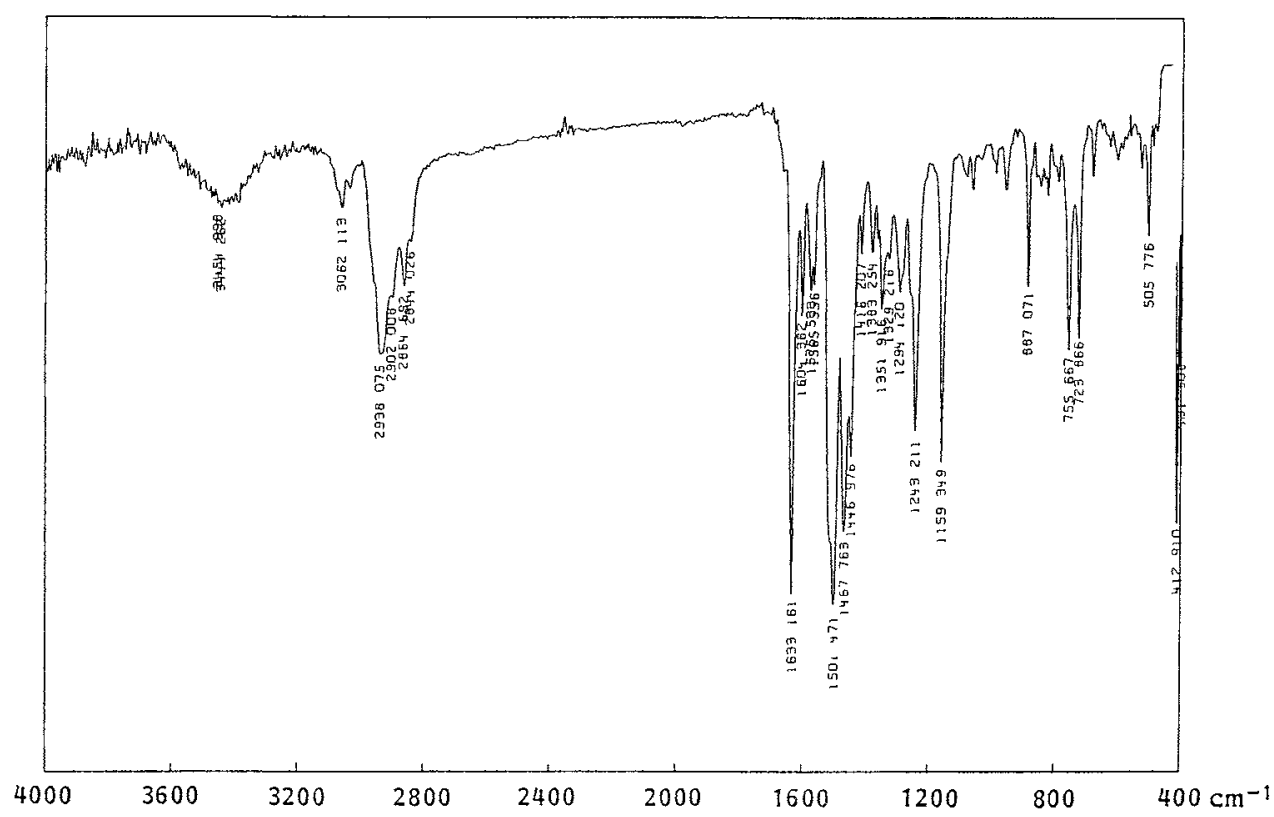

Fig. 3. ${ }^{13} \mathrm{C}$ NMR spectrum of phenazinomycin $\left(125 \mathrm{MHz}, \mathrm{CD}_{3} \mathrm{OD}\right)$.

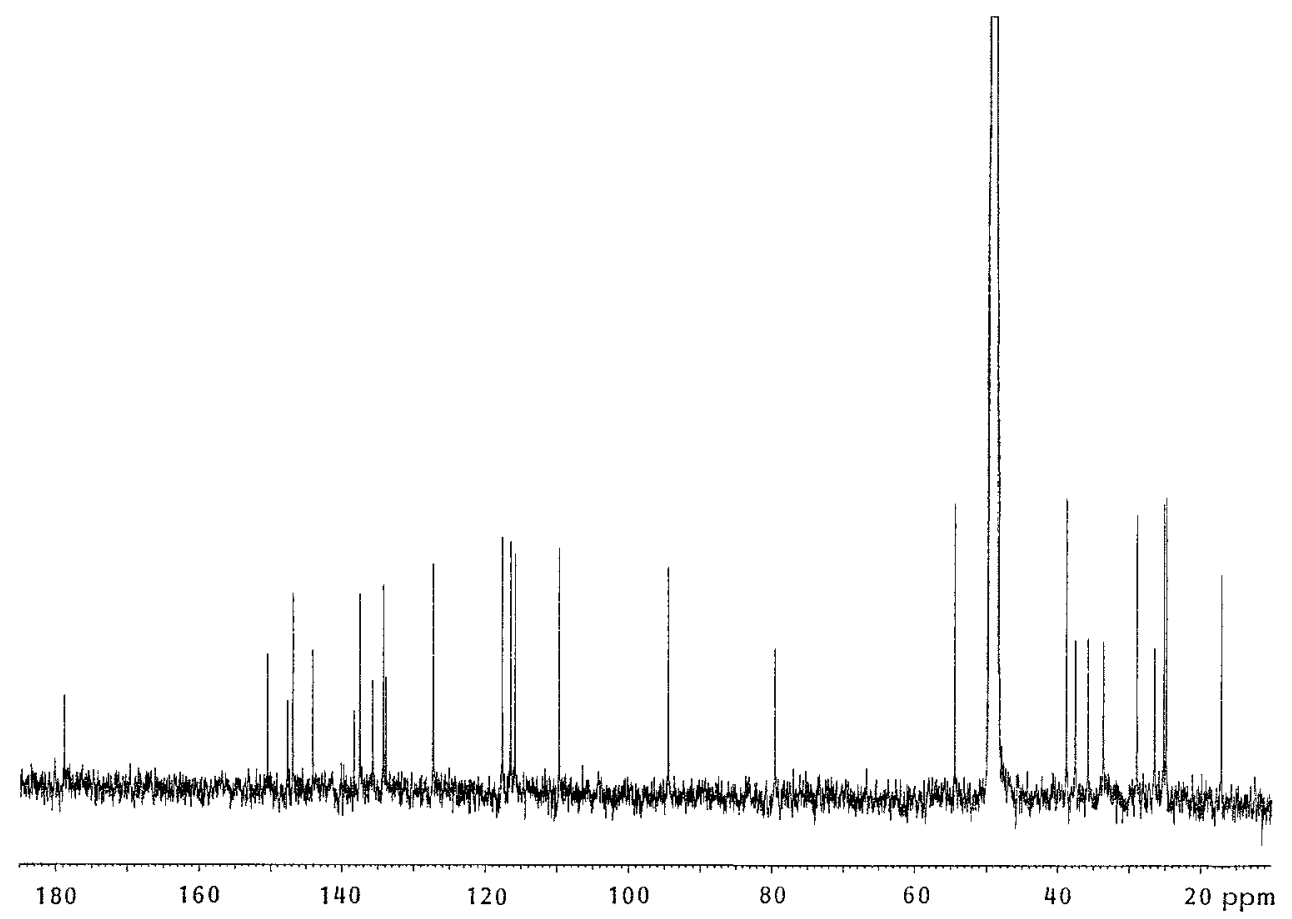

The antitumor activity of phenazinomycin on Sarcoma 180 is shown in Table 5. The antibiotic caused a prolongation of survival time for tumor-bearing animals. The antitumor spectrum on a variety experimental tumors of phenazinomycin will be reported elsewhere. 
Physico-chemical Properties of Phenazinomycin

Physico-chemical properties of phenazinomycin are summarized in Table 6. This antibiotic is soluble in $\mathrm{MeOH}$, EtOH, $\mathrm{CH}_{2} \mathrm{Cl}_{2}$, $\mathrm{CHCl}_{3}, \mathrm{EtOAc}, \mathrm{BuOAc}$ and acetone, but practically insoluble in $\mathrm{H}_{2} \mathrm{O}$ and $n$-hexane. The IR and ${ }^{13} \mathrm{C}$ NMR spectra of phenazinomycin are shown in Figs. 2 and 3, respectively. In the electron impact mass spectrum (EI-MS) of this compound, a molecular ion peak was observed at $m / z$ 400. The molecular formula of phenazinomycin was elucidated by high resolution mass spectrometry; observed: $m / z$ 400.2510; calcd for $\mathrm{C}_{27} \mathrm{H}_{32} \mathrm{~N}_{2} \mathrm{O}$ : 400.2516. The structure of phenazinomycin (Fig. 4) was established on the basis of spectral analyses and chemical degradation studies and details of the structure elucidation of phenazinomycin will be reported in a separate paper $^{53}$.

\section{Acknowledgment}

This work was supported, in part, by Grants-in-Aid from the Ministry of Health and Welfare and the Ministry of Education, Science and Culture, and by funds from the Japan Keirin Association. The authors would like to thank Mr. M. FURUKANE, The Kitasato Institute, for his assistance with the fermentation of Streptomyces sp. WK-2057.

\section{References}

1) Shirling, E. B. \& D. Gottlieb: Methods for characterization of Streptomyces species. Int. J. Syst. Bacteriol. 16: 313 340, 1966

2) Color Harmony Manual, 4th Ed. Container Corporation of America, Chicago, 1958

3) Pridham, T. G. \& D. Gottlieb: The utilization of carbon compounds by some Actinomycetales as an aid for species determination. J. Bacteriol. 56: 107 114, 1948

4) BeCKer, B.; M. P. Lechevalier \& H. A. Lechevalier: Chemical composition of cell-wall preparations from strains of various form-genera of aerobic actinomycetes. Appl. Microbiol. 13: 236 243, 1965

5) Funayama, S.; S. Eda, K. Komiyama, S. OMura \& T. Tokunaga: Structure of phenazinomycin, a novel antitumor antibiotic. Tetrahedron Lett. 30: 1989, in press 